\title{
Recurring features of extreme autumnall rainfall events on the Veneto coastal area
}

\section{A. Barbi, M. Monai, R. Racca, and A. M. Rossa}

ARPAV, Regional Agency for Environmental Prevention and Protection of the Veneto, DRST, Land Safety Department, CMT, Meteorological Centre of Teolo, Italy

Correspondence to: A. Barbi (abarbi@arpa.veneto.it)

Received: 25 February 2011 - Revised: 29 August 2011 - Accepted: 1 October 2011 - Published: 7 August 2012

\begin{abstract}
Recent recurring episodes of heavy flash floodproducing rainfall events on the Veneto coastal area have renewed the interest in documenting the frequency and key dynamical ingredients of such events. A climatological analysis of the precipitation in Veneto reveals that, in comparison with the rest of the region, the coastal area is characterized by fewer rain days, lower rainfall accumulations, yet more days with heavy precipitation. If set in relation to the yearly rainfall, daily accumulation can reach values as high as $40 \%$ of the yearly total rainfall, more regularly between $15 \%$ and $30 \%$, often in periods of $12 \mathrm{~h}$ or less.
\end{abstract}

Four such heavy rainfall events were analyzed and synthetically described to highlight key ingredients which appear instrumental in producing the high rainfall accumulations. These comprise an upper-level trough elongating or cutting off into the Western Mediterranean basin after a period of one to two weeks of anticyclonic fair weather conditions with temperatures above normal. The moisture supply over the Adriatic onto north-eastern Italy is favoured by above normal sea surface temperatures, enhanced advection by a surface low in the Gulf of Genoa, and in three of the four cases, an additional surface low over southern Italy. The air flows associated with the upper-level trough for the cases discussed were of moderate to weak intensity, and convectively conditionally unstable. The flow intensity was such that the lower tropospheric portion was blocked by and forced to flow around the Alpine barrier, i.e. manifesting as a north-easterly, low-level flow over much of the north-eastern Italian plains. This blocked flow seemed to interact with the larger-scale synoptic flow to form a distinct and persistent low-level convergence in the area of the Veneto coast.

It is suggested that these low-level convergence patterns are key in releasing the convective instability present in the larger-scale flow just on the Veneto coastal area. Hereby, it is the synoptic rather than the convective setting which dictated the observed timescales of intense rainfall. Therefore, the convective rainfall rates paired with the synoptic durations combine to produce the exceptionally high rainfall accumulations observed. Cases like these are significant contributors to forming the coastal precipitation climatology, which for this area is found to be distinctly different than for the rest of the region in terms of precipitation concentration.

\section{Introduction}

Recent episodes of heavy precipitation in the flat coastal areas of the Po Valley portion of the north-eastern Italian region Veneto have prompted this descriptive study, which aims at understanding the main dynamic mechanisms common to these events and documenting their frequency. The Veneto coast hosts significant touristic activities, not least the attraction of Venice city and a number of beaches requiring specific attention from the Veneto Regional Meteorological Service, especially during the warm season. The Centro Meteorologico di Teolo (CMT), part of the Regional Agency for Environmental Prevention and Protection of the Veneto (ARPAV), hold this role and operate a multi-sensor monitoring network for this purpose.

Although flat, the Po Valley in Veneto is fringed by the Alpine barrier at a distance of less than $100 \mathrm{~km}$ to the north of the Adriatic Sea, making an orographic influence on the atmospheric flow likely also on the coastal area, especially in southerly flow configurations. As a matter of fact, during the Mesoscale Alpine Programme (MAP, Bougeault et al., 2001), synoptically forced, large-scale flows with a 
predominant southerly component towards the Alps were studied as they are known for their potential to produce heavy precipitation on the southern side of the Alps (Rotunno and Houze, 2007). Environmental static stability, strength of the flow and height, breadth and shape of the mountain determines to what extent the air will flow over the barrier or was blocked and forced to flow around it, as well as where the major precipitation accumulation will occur. Rotunno and Houze (2007) document the fundamental difference between two synoptically very similar events which exhibit completely different precipitation structures. One key difference between these two cases, IOP2b and IOP8 of the MAP Special Observing Period (SOP), was found to be in the low-level static stability, which was small for IOP2b with a consequent prevailing flow-over regime but large for IOP8 with a consequent flow blocking and flow reversal in the lowest layers, which prevented large precipitation accumulations upon the orography in the Lago Maggiore target area.

In Veneto, the prevailing wind direction is from easterly, north-easterly sectors in a climatology which is generally characterized by low winds. These moderate to occasionally strong winds are often termed Bora in a generic sense, but exhibit different dynamic origins. One mechanism giving rise to north-easterly winds is observed to be linked to blocked low-level flow in synoptic conditions inducing flows from southerly sectors, associated with upper-level troughs extending or cutting off into in the Mediterranean area (Monai et al., 2006). As a matter of fact, for a winter case Monai et al. (2006) show that the interaction of southerly Sirocco winds with a redirected blocked low-level flow from the north-east led to a distinct flow convergence in the proximity of the coast with consequent precipitation. Forecaster experience and selected documented cases for Veneto (Monai et al., 2005) show that the stronger the flow, the more precipitation is reaching the surface to the north on the mountain barrier from the prealpine chain to the more northerly Dolomite mountains.

The precipitation climatology in Veneto follows a classical pattern with moderate average accumulation in the flat part and the coast, increasing towards the first orographic barrier, the pre-alpine chain, and decreasing behind it. This indicates that, on average, warm-humid flows impinge on the prealpine chain with consequent maximal precipitation accumulation where the orographic influence is most pronounced. Such a climatology does not, however, sort out intense precipitation events. Martin-Vide (2004) proposed a synthetic way of highlighting to what extent the precipitation climatology is a result of frequent moderate or rare heavy precipitation events, defining a concentration index $(\mathrm{CI})$, which varies from zero (equal precipitation accumulation for each rain day) to one (all precipitation accumulation in one rain day). Application to the Spanish rain gauge network revealed a distinct band of maximum CI values (0.65-0.71) along the northern Mediterranean coast.
In this paper, a concise description of the Veneto precipitation climatology is presented in terms of average accumulation, extreme values of daily accumulation, and the distribution of extreme daily values as expressed by the CI. Then, four recent cases of heavy precipitation in the coastal area of Veneto are examined in terms of synoptic and mesoscale flow configuration and compared to the precipitation climatology. All four cases occurred in September, which can be considered a transition month between baroclinically weakly forced summer and more strongly forced autumnal weather systems.

In the second section of the paper, the data sets used in this study are briefly described while selected considerations on the precipitation climatology of the region are given in Sect. 3. Section 4 reports the results, whereas some conclusions are summarized in the final section.

\section{Data sets}

The CMT multi-sensor monitoring network comprises about 200 meteorological and hydrological surface stations, two meteorological C-band radars and one X-band radar, a Meteosat receiver station, and eight boundary layer profilers of which four passive microwave profilers for temperature retrievals, and four sodars for wind retrievals. For the present study, data from the automatic surface station network and the C-band Doppler radars were analyzed. The two radars, both EEC single polarization Doppler radars working at Cband, are located on Mt. Grande (472 m a.s.1.) on the central part and at Concordia Sagittaria (0 m a.s.l.) on the eastern part of the Veneto plain (Fig. 1).

The climatological analysis for precipitation was performed for the period 1993-2009 and the ARPAV rain gauge network, installed and maintained by the Centro Meteorologico di Teolo. Precipitation observations, obtained from tipping bucket gauges and archived in 5 min intervals, undergo daily automatic and manual quality control procedures. Wind observations are obtained by classical cup anemometers mounted $10 \mathrm{~m}$ above the surface as ten-minute averages of instantaneous winds. The average yearly precipitation accumulation was evaluated for a different set of rain gauges which were used spanning the thirty-year period 1971-2000. These stations belonged to several institutions in the past. The interpolation was done by ordinary Kriging without any external drift of correction. The CI was evalutated on a different data set for two reasons, i.e. the ARPAV rain gauge network had a higher spatial resolution and spanned the recent years in which the four cases analyzed in this paper took place. Secondly, the 1971-2000 data set is not entirely available for the years 2001-2009.

Radio soundings used to characterize the airmasses for the four cases were taken from the Bologna S. Pietro Capofiume (WMO code 16144) and Udine Campoformido (WMO code 16044) stations, while sea surface temperature was 


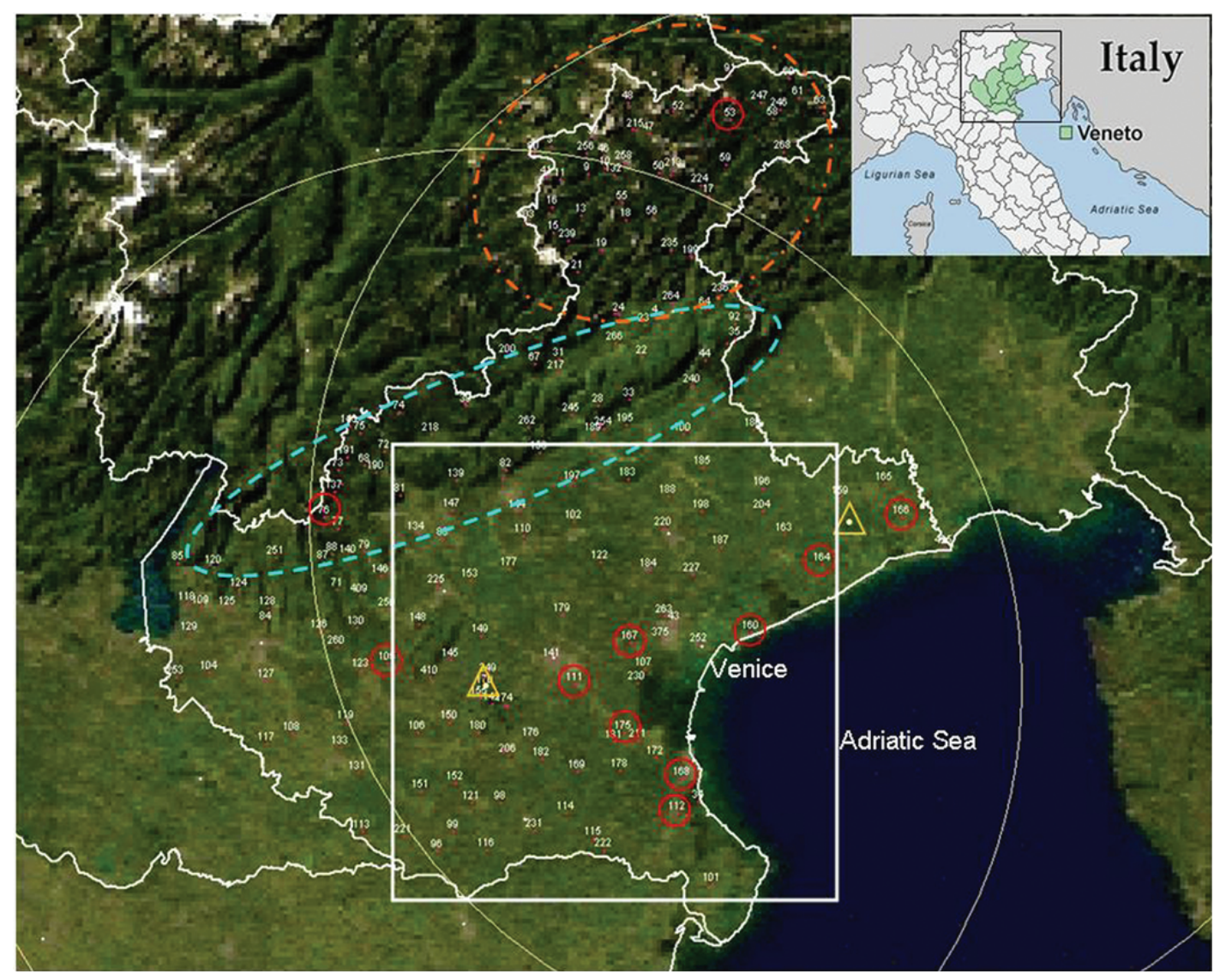

Fig. 1. Geographical map of the north-eastern Italian region Veneto with orography (colour shading, light colours indicate low elevations, dark colours high elevations, white the higher mountain peaks), radar locations (triangles) with respective $128 \mathrm{~km}$ range rings (large circles), meteorological surface stations (code numbers). The small circles denote the stations used for the climatological analysis. The CALMET domain used for the surface wind interpolation is outlined by the white rectangle, the prealpine area and the Dolomite mountains by the dashed and dash-dotted ellipses, respectively.

obtained by two buoys located off shore Trieste and Lignano, kindly provided by the Meteorological Service of ARPA Friuli Venezia Giulia. The synoptic conditions during and prior to the events are described using the NCEP - NCAR reanalysis (National Centre for Atmospheric Research - National Centre for Environmental Prediction, Kalnay et al., 1996).

Surface convergence fields were assessed by interpolating the ARPAV automatic weather station network plus a buoy observation located some $30 \mathrm{~km}$ offshore the Venice Lagoon. Interpolation was done by means of the CALMET model which is a meteorological pre-processor for air quality and dispersion modelling (Scire, 2000). Besides retrieving the temperature field and a number of micro meteorological variables, such as the friction velocity, the Monin-Obukhov length and the boundary layer mixing height, it performed the gridding of the 10-m wind field from 30 selected ARPAV automatic weather stations, 9 SYNOP stations, and three radio sounding stations. The latter, although located outside of the CALMET domain, helped to improve the interpolation in the border area of the domain (see Fig. 1 for the CALMET domain), which was done by orographic adaptation and minimization of the horizontal divergence. Calculation of the convergence field was then performed by a finite difference scheme. Hereby, the smoothness constraint imposed by CALMET can act on the local wind field in a way that reduces the real convergence values obtained for the horizontal wind field. Significant convergence signatures obtained in this way can be seen as lower limits and smoothed versions of the real convergence.

\section{Climatological features of the Veneto coastal area}

The north-western end of the Adriatic Sea constitutes the Veneto coastal area which borders the region on its south eastern portion. It is a region of transition between continental Central Europe and the Mediterranean, with different meso-climatic regimes which are closely linked to the topography and the presence of the Adriatic Sea. As a matter 


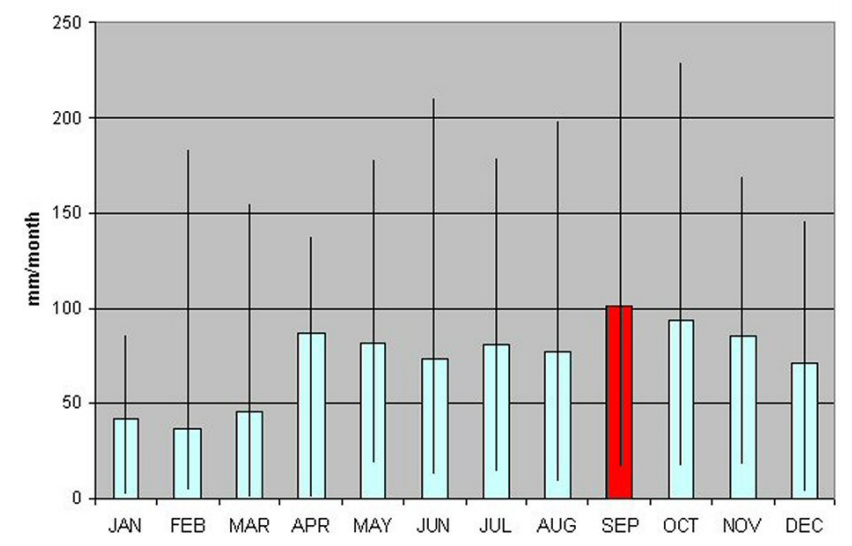

Fig. 2. Distribution of monthly precipitation on Mira (province of Venice) for the period 1993-2009. Histograms represent the average monthly precipitation accumulations $(\mathrm{mm})$, black lines show minimum and maximum values of the monthly series.

of fact, the mountaineous area, including the pre-alpine chain and the Dolomite mountains, the flat Po Valley portion and the coastal area exhibit distinct climatic characteristics. In particular during the warm season, due to the proximity of the sea with the frequent humid and slightly cooler sea breeze the coastal climate differs from the more continental Po Valley climate, with more pronounced annual and daily temperature excursions. Mesoscale circulations in fair weather anticyclonic conditions are in line with the typical coastal wind regimes and dominated by the sea breeze circulation from the east and south east in the afternoon, whereas the nocturnal flow is more complex and from the north-east; it is not perpendicular but parallel to the coast due to the effects on the pressure field induced by horizontal temperature gradients associated with unequal nocturnal cooling of the Alps and the adjacent lowland regions (Camuffo et al., 1979; Barbi et al., 2005).

The precipitation accumulation climatology does not reveal particular differences to the rest of the flat Veneto Po Valley portion, with the southern part being the driest of the region with approximately $700-1000 \mathrm{~mm}$ of mean annual rainfall, whereas quantities of more than $2000 \mathrm{~mm}$ are measured on parts of the pre-alpine chain located only $100 \mathrm{~km}$ apart. It is quite obvious that these differences are mainly related to the mountain barrier and its interaction with southerly warm and humid currents coming from the Mediterranean Sea (Smith, 1979). The intra-annual mean monthly precipitation cycle for the coastal area rain gauge station Mira (Fig. 2), shows two relative maxima in the synoptically more active spring and autumn seasons, and a distinct minimum in winter with frequent persistent anticyclonic and therefore dry conditions. Note, that September is the rainiest month with $100 \mathrm{~mm}$ average monthly accumulation, and it features the maximum monthly value accumulation of $250 \mathrm{~mm}$.

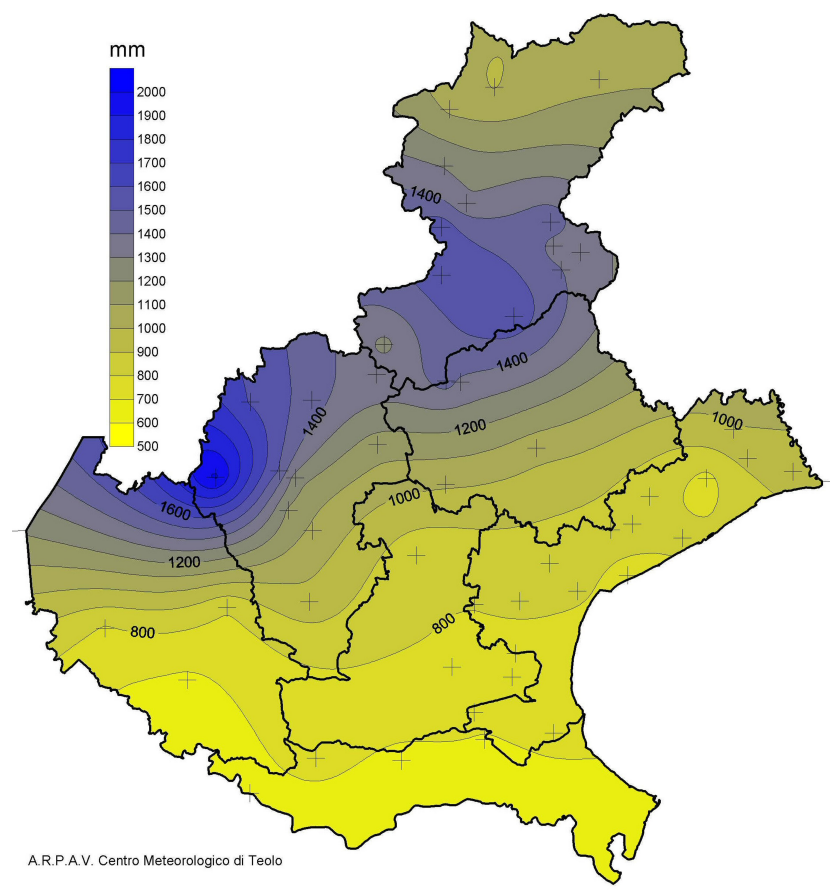

Fig. 3. Spatial distribution of mean total annual rainfall as obtained for the period 1971-2000 by Kriging interpolation of 60 rain gauge stations (indicated as crosses).

The precipitation climatology compiled for the period 1993-2009 for eight rain gauge stations located in the Veneto coastal area is summarized in Table 1 . The mean total annual precipitation (column " $P$ annual") is relatively modest on the coastal area, it records about 700-1000 mm (from the lowest value of $708 \mathrm{~mm}$ for the Rosolina rain gauge station at the southern position of the Veneto coast, to the highest value of $934 \mathrm{~mm}$ for the Lugugnana rain gauge station at the northern position of the Veneto coast) with a coefficient of variation ("CV\%"), defined as the standard deviation normalized by the mean, greater than $20 \%$ for many stations and a maximum value of $24 \%$ at the northern position of the Veneto coast. The mean annual values of rainy days (" $N$ yrd") are the lowest in Veneto for these stations, some not even reaching 80 rain days per year. The averaged precipitation of the rainiest month (" $P$ monthly") reaches values greater than $100 \mathrm{~mm}$ for some stations, with a relatively high coefficient of variation ("CV\%") of values ranging from 51 to $78 \%$ for the 8 stations analysed. The rainiest month ("month") is September (October for rain gauge station Lugugnana). The maximum daily precipitation (" $P \max$ daily") is very high, reaching a maximum value of $254 \mathrm{~mm}$ for the 8 stations analyzed. These daily precipitation accumulations can be considered extreme and assume greater importance if compared with the mean total annual; in fact the weight of the maximum daily precipitation in the mean total annual amount ("\% $P$ annual") reaches values of about $15-30 \%$ and more. 
Table 1. Precipitation climatology summary for the period 1993-2009 and a number of rain gauge stations on Veneto coastal area.

\begin{tabular}{|c|c|c|c|c|c|c|c|c|c|c|}
\hline Station & Cod & $\begin{array}{r}P \text { annual } \\
(\mathrm{mm})\end{array}$ & $\begin{array}{l}\mathrm{CV} \\
(\%)\end{array}$ & $\begin{array}{r}N \\
\text { yrd }\end{array}$ & $\begin{array}{r}P \text { monthly } \\
(\mathrm{mm})\end{array}$ & (month) & $\begin{array}{l}\mathrm{CV} \\
(\%)\end{array}$ & $\begin{array}{r}P \max \\
\text { daily }(\mathrm{mm})\end{array}$ & $\begin{array}{r}\% P \\
\text { annual }\end{array}$ & (month) \\
\hline Lugugnana di $\mathrm{P}$. & 166 & 934 & 24 & 84 & 108 & Oct & 78 & 143 & 15 & Nov \\
\hline Eraclea & 164 & 873 & 23 & 82 & 103 & Sep & 53 & 139 & 16 & Sep \\
\hline Cavallino Trep.ti & 160 & 863 & 21 & 76 & 111 & Sep & 51 & 158 & 18 & Sep \\
\hline Chioggia & 168 & 798 & 22 & 76 & 105 & Sep & 58 & 254 & 32 & Sep \\
\hline Rosolina & 112 & 708 & 23 & 74 & 90 & Sep & 51 & 177 & 25 & Sep \\
\hline Mira & 167 & 875 & 21 & 80 & 102 & Sep & 65 & 169 & 19 & Sep \\
\hline Codevigo & 175 & 802 & 19 & 78 & 97 & Sep & 56 & 160 & 20 & Sep \\
\hline Legnaro & 111 & 833 & 22 & 79 & 89 & Sep & 53 & 169 & 20 & Sep \\
\hline
\end{tabular}

From Fig. 3 one can readily see a clear south to north gradient in the mean total annual rainfall as calculated for the period 1971-2000. This spatial pattern is evidently related to the the strong orographic signature of the region, which rises from the southern plain at $20 \mathrm{~m}$ or less above sea level to the first orographic barrier, the pre-alpine chain, to about 1500$1800 \mathrm{~m}$ a.s.l. and then further to the north to the Dolomites, a mountain massive that peaks at over $3000 \mathrm{~m}$ a.s.l. As a matter of fact, the maximum annual values are found along the prealpine chain, whereas the Dolomites appear to be screened by the pre-alpine chain, as the average annual precipitation accumulations are significantly lower than on the former. On the coastal area, the mean of total annual rainfall reaches the lowest values of the region with $700-1000 \mathrm{~mm}$ of average annual precipitation.

In the pre-alpine area, as in other regions on the southern side of the Alps, the high values of precipitation accumulation are strongly linked to the orographic forcing, especially efficient in southerly warm and humid flows coming from the Adriatic Sea; these are synoptic conditions which favour long-lasting precipitation events just on the pre-alpine barrier. Conversely, the precipitation accumulation on the coastal area is often linked to heavy convective rainfall events affecting this area in late summer/early autumn. The regional analysis of maximum heavy precipitations for $1 \mathrm{~h}$ to $12 \mathrm{~h} \mathrm{du}-$ ration evidences highest values along the coast and portions of the neighbouring flatlands. Also, the same area exhibits the highest ratios of maximum daily to mean annual rainfall accumulation, which can be as high as $20-30 \%$, occasionally even higher (Table 1).

To further elaborate on this, a more detailed analysis of daily rainfall distributions is performed to highlight an interesting feature common to other coastal Mediterranean areas. During the fall season the sea surface temperature is still warm and provides ample moisture which can give rise to torrential rainfall events which account for a substantial fraction of the annual rainfall (Romero et al., 1999; Homar et al., 2002; Lionello et al., 2006; Martin-Vide, 2004; Lebeaupin et al., 2006; Miglietta and Regano, 2008). This is to say that the precipitation regime in such areas seems to concentrate a significant portion of the annual rainfall into very short periods of time in the form of what often turns out to be an extreme event with deep convection playing a central role. To quantify this, a method proposed by Martin-Vide (2004) is applied, which consists in synthesizing the contribution of daily precipitation to the total amount into a concentration index (CI) for a number of Veneto rain gauge stations for the period 1993 to 2009. To this end, all days with non-zero precipitation are ranked according to the rainfall accumulation and then plotted in a sort of cumulative diagram as shown in Fig. 4: the cumulative percentage of rain days, Sum Ni (\%) or $X$, is plotted against the cumulative percentage of rainfall amount, Sum $\mathrm{Pi}(\%)$ or $Y$. Note that the resulting polygonal line, here for the station of Legnaro (code 111), is markedly exponential. The diagonal of this diagram denotes the equidistribution line, which represents the idealized case in which the total precipitation is accumulated in days with equal daily precipitation accumulations. The rainfall concentration (or daily irregularity of the rainfall) can be represented as the separation or area between the concentration curve and the equidistribution line. This area is defined as the concentration index $(\mathrm{CI})$, which is a measure of how much the overall rainfall is concentrated in only a few of all the rainy days (high values, CI tending to one) or is evenly distributed over many of all the rainy days (low values, CI tending to zero).

The precipitation concentration curves along with the CIs were evaluated for eleven rain gauge stations (Fig. 1), eight of which are located in the coastal area, one some $70 \mathrm{~km}$ inlands on the plain, one on the pre-alpine chain, and one in the Dolomites. The corresponding CI and the percentage of precipitation contributed by the $25 \%$ rainiest days, were calculated and are shown in Table 2. Note that high CI, with values around 0.70 for rain gauge stations Mira, Eraclea and Chioggia we are found on the coastal area where the $25 \%$ rainiest days contribute $80-81 \%$ of the total precipitation. Inlands, the CI is 0.61 for Lonigo, where the $25 \%$ rainiest days contribute $72 \%$ of the total rainfall; for the prealpine rain gauge Turcati, the rainiest area of Veneto, the CI results are 0.64 with the $25 \%$ rainiest days accounting for $76 \%$ of the total precipitation. A positive correlation $(+0.64$, 
Table 2. Precipitation concentration index computed for the period 1993-2009 for the eleven rain gauge stations marked in Fig. 1, eight of which are located the in the coastal area, one some $70 \mathrm{~km}$ inland on the plain (Lonigo), one on the pre-alpine chain (Turcati), and one in the Dolomites (Auronzo). Pannual is the mean of total annual precipitation, CI is the Concentration Index and $P \%$ of $25 \%$ rainiest days denote the percentage of precipitation contributed by the $25 \%$ rainiest days.

\begin{tabular}{llrrrrr}
\hline Area & Station & Cod & $\begin{array}{r}\text { Alt. } \\
(\mathrm{m})\end{array}$ & $\begin{array}{r}P \text { annual } \\
(\mathrm{mm})\end{array}$ & CI & $\begin{array}{r}P \% \text { of } 25 \% \\
\text { rainest days }\end{array}$ \\
\hline \multirow{6}{*}{ Coast } & Lugugnana di P. & 166 & 0 & 934 & 0.69 & 79.5 \\
& Eraclea & 164 & -1 & 873 & 0.70 & 80.0 \\
& Cavallino Treporti & 160 & 1 & 863 & 0.67 & 77.2 \\
& Chioggia (S.Anna) & 168 & -1 & 798 & 0.70 & 81.0 \\
& Rosolina & 112 & -2 & 708 & 0.66 & 75.8 \\
& Mira & 167 & 5 & 875 & 0.70 & 80.5 \\
& Codevigo & 175 & 0 & 802 & 0.69 & 79.6 \\
& Legnaro & 111 & 8 & 833 & 0.69 & 78.9 \\
\hline \multirow{4}{*}{ Inland } & Lonigo & 105 & 28 & 810 & 0.61 & 72.1 \\
& Turcati & 76 & 705 & 2153 & 0.65 & 75.6 \\
& Auronzo & 53 & 849 & 1153 & 0.62 & 72.8 \\
\hline
\end{tabular}

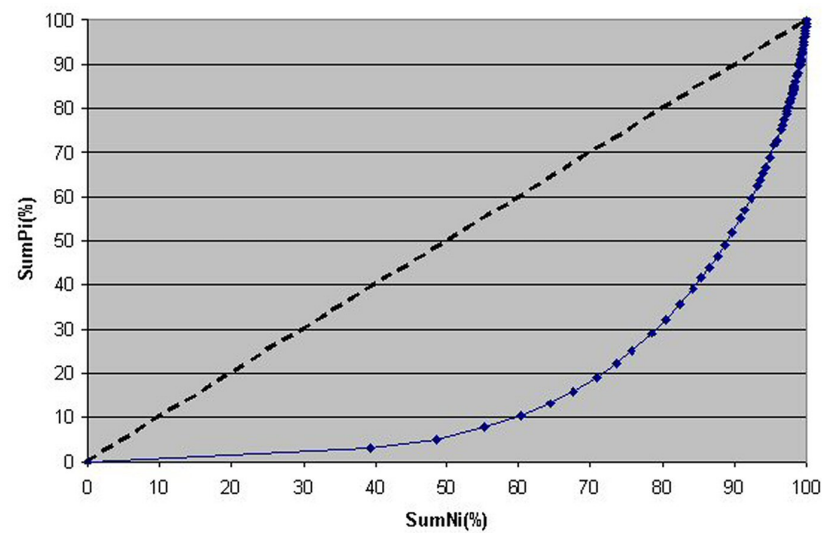

Fig. 4. Example of accumulated number of precipitation days (Sum $\mathrm{Ni}$ ) versus amount of accumulated precipitation (Sum Pi) for the Legnaro station. The blue line is the so-called concentration curve of precipitation, the dashed line represents the equidistribution line, i.e. the case in which the total precipitation is accumulated in days with equal daily precipitation accumulations.

significance $<0.05)$ emerges between the $\mathrm{CI}$ and maximum daily rainfall compared to the mean annual amount (\%). The results obtained are in agreement with other similar studies performed in Mediterranean areas (De Luis et al., 1997; Martin-Vide, 2004).

In summary, the precipitation climatology of the Veneto coastal area seems to share characteristics common to other Mediterranean coastal areas, in that the:

- mean total annual rainfall is relatively low if compared with neighbouring areas;
- maximum daily rainfall accumulations can be very significant, especially compared with mean annual amount;

- the level of concentration in the distribution of daily precipitation is significantly larger than for areas located away from the coast.

\section{Analysis of four recent coastal area flash flood events}

In this section, four cases of heavy precipitation in the Veneto coastal area are presented in order to illustrate and substantiate the climatological analysis in Sect. 3. As a matter of fact, in September of each of the four years from 2006 to 2009 a flash flood-producing heavy rainfall event affected the coastal area. A concise case description is given for each event in terms of the synoptic setting and the prevailing synoptic conditions seven to ten days prior to the event (Figs. 5, 6 and 7), airmass stability and flow intensity (Table 4), the main precipitation characteristics as observed by the ARPAV Doppler radar network (Fig. 1), mesoscale surface wind and convergence patterns (Fig. 9), and a pluviometric analysis (Fig. 10). This is done with the aim of distilling common key ingredients which combine to yield the observed extreme rainfall accumulation. The four heavy rainfall events which were analyzed occurred on 17 September 2006, 26 September 2007, 13 September 2008, and 16 September 2009.

\subsection{September 2006 case}

The synoptic conditions on 17 September 2006 (Fig. 5a) were characterized by a North Atlantic upper-level trough approaching the Western Mediterranean basin, cutting off over the Italian Peninsula and generating a surface low over 

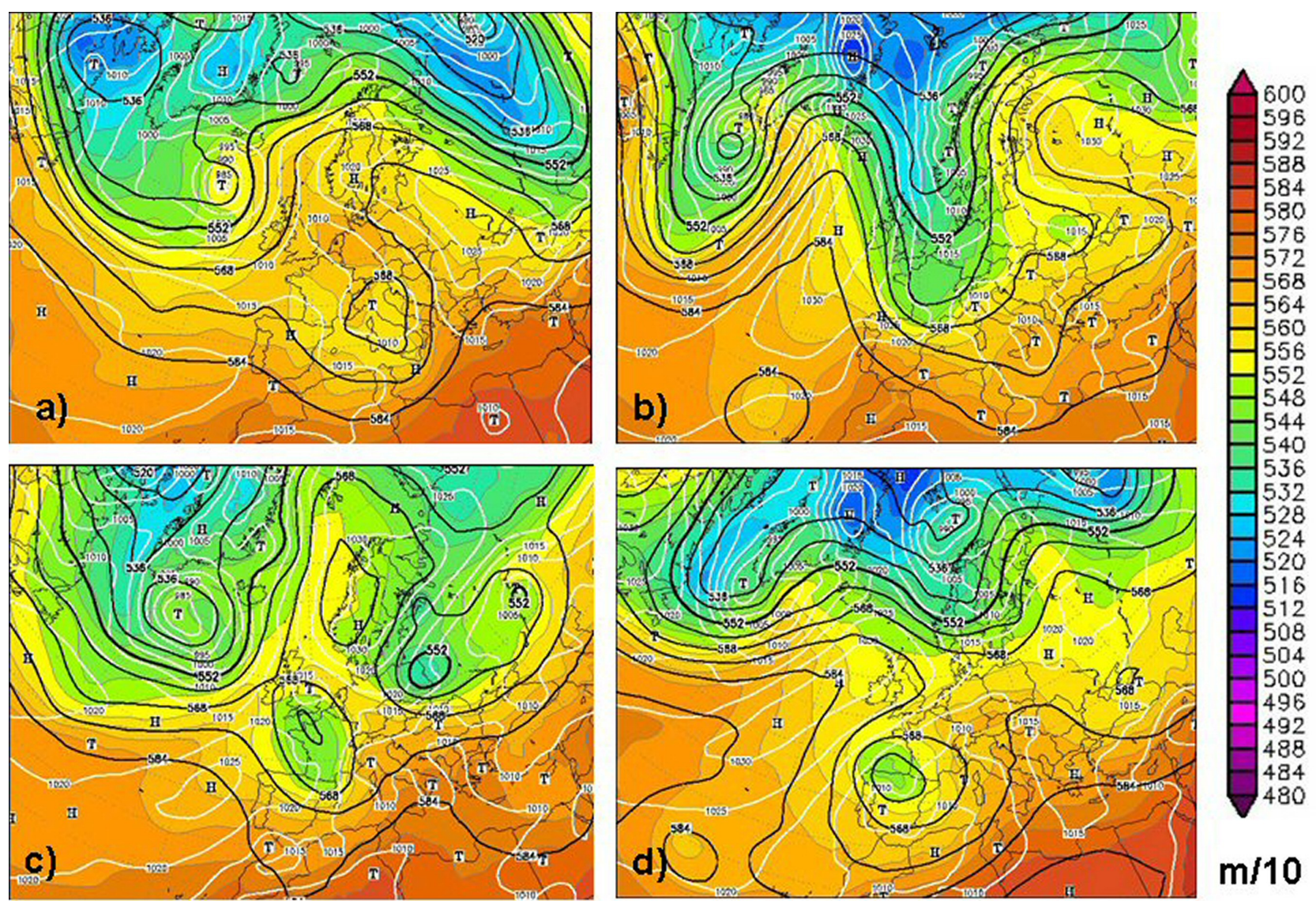

Fig. 5. NCEP/NCAR reanalysis sea level pressure (hPa, white lines), $500 \mathrm{hPa}$ geopotential height (dam, black lines) and relative topography between $500 \mathrm{hPa}$ and $1000 \mathrm{hPa}$ (dam, colour shading) on 17 September 2006, 00:00 UTC (panel a), 26 September 2007, 00:00 UTC (panel b), 13 September 2008, 00:00 UTC (panel c), and 16 September 2009, 12:00 UTC (panel d), (source: http://www.wetterzentrale.de).

northern Italy. A residual tongue of warm and moist air extended from the south-eastern Mediterranean basin to the Balkans and was associated with a high pressure system centred over Russia. An upper-level ridge extended from North Africa over the Mediterranean during the ten days prior to 14 September, while the surface-level pressure field was conditioned by a persistent high over Eastern Europe (Figs. 6a and 7a). From 14 to 16 September 2006, scattered convection took place on the entire region, associated with the approaching synoptic perturbation, which produced the heavy rainfall event on 17 September 2006.

Starting around 00:00 UTC a widespread and coherent precipitation system with embedded convective activity formed over most of the Veneto coastal area and was fed by and propagated with the south-easterly flow onto the eastern Veneto plain. The intensity of the convective cells was moderate with reflectivity values between 40 and $50 \mathrm{dBZ}$ and tended to fade as the cells propagated away from the coastal area toward the pre-alpine chain. This convective activity continued much through the entire day, but was more widespread until the early morning hours and became more localized throughout the morning until early afternoon. By late afternoon, the precipitation was concentrated over the central and southern coastal area with continued embedded convection of moderate intensity. The rainfall activity subsequently propagated southwards and weakened by the early morning hours of 18 September. During the most intense phases of the event, an area of convergence between a southeasterly flow on the Adriatic and a north-easterly flow inland was clearly picked up by the ARPAV automatic weather station network. This flow interaction is likely to have contributed to the persistence of the precipitation localization, while the convective activity was favoured by the conditional instability present in the airmass (Fig. 9a). As a matter of fact, as reported in Table 4, the flow intensity was moderate to weak with about $16 \mathrm{kn}$ at the $500 \mathrm{hPa}$ level, while the difference in equivalent potential temperature between this level and the surface, was distinctly negative amounting to 6-7 K. The weak flow is consistent with the conceptual model of a low-level blocked flow, forcing a distinct low-level convergence pattern, which triggered the release of the convective instability over this particular area, well upstream of the first orographic barrier. 

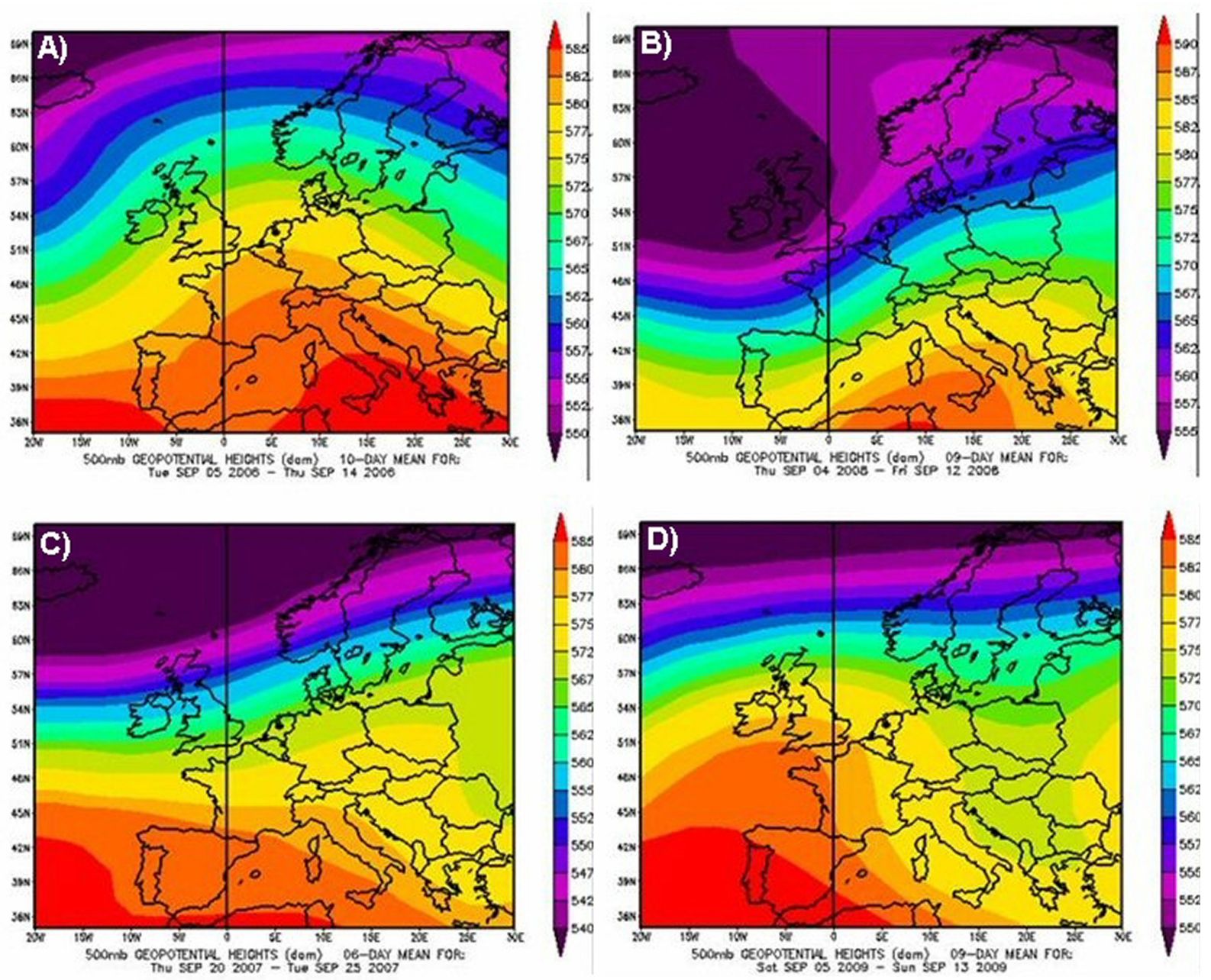

Fig. 6. $500 \mathrm{hPa}$ geopotential height (dam) averaged over a ten-day period prior to the heavy rainfall events of $17 \mathrm{September} 2006$ (A), 26 September 2007 (B), 13 September 2008 (C), and 16 September 2009 (D). Images obtained from NOAA/ESRL Physical Sciences Division, Boulder Colorado at http://www.esrl.noaa.gov/psd.

The pluviometric analysis shows that the heavy persistent rainfall recorded over the central coastal area (Fig. 10a) yielded a maximum total accumulation of $153 \mathrm{~mm}$ for the Valle Averto rain gauge station and $111 \mathrm{~mm}$ for the Mira rain gauge station in a localized area close to Venice Lagoon with maximum rain rates of $121 \mathrm{~mm}$ and $101 \mathrm{~mm}$ in $12 \mathrm{~h}$ and a maximum intensity close to $50 \mathrm{~mm} \mathrm{~h}^{-1}$ recorded in $5 \mathrm{~min}$.

\subsection{September 2007 case}

On 26 September 2007 (Fig. 5b) a meridionally elongated upper-level trough extended from Scandinavia into the Western Mediterranean associated with a cold air advection and gave rise to a lee cyclogenesis over the Gulf of Genoa. A second pressure minimum was present over southern Italy, contributing to enhance the south-easterly moist flow over the Adriatic Sea. The antecedent synoptic situation was characterized by prevailing anticyclonic conditions over the
Mediterranean basin in the form of an upper-level ridge extending from North Africa to the Balkans, especially during the period from 20 to 25 September and connecting to the eastward extending high pressure system of the Azores (Figs. 6b and 7b).

This case was described in some detail in Barbi et al. (2008) in relation to the rain gauge analysis, in Rossa et al. (2010a) in relation to the potential of the radar observations for such localized cases, in Rossa et al. (2010b) in relation to the predictability and hydrological forecasting of the event, and in Davolio et al. (2009) in relation to the predictability of the episode using a number of high resolution, convection resolving models. In the early and morning hours, the surrounding areas of Venice were hit by extreme rainfall caused by severe thunderstorms which developed close to the central-southern Veneto coastline. Convective cells started just after midnight inlands producing isolated thunderstorms 

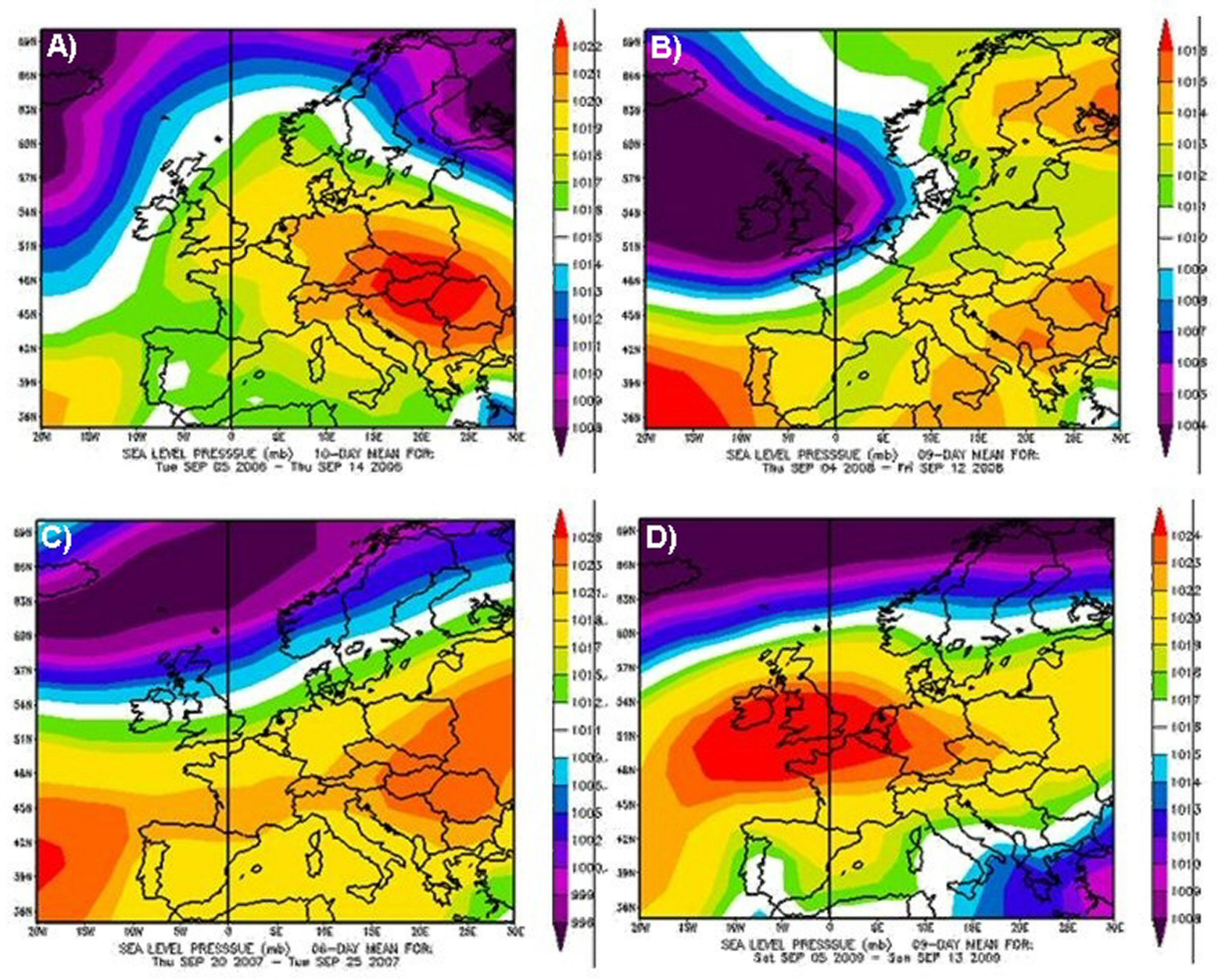

Fig. 7. Sea level pressure (hPa) averaged over a ten-day period prior to the heavy rainfall events of 17 September 2006 (A), 26 September 2007 (B), 13 September 2008 (C), and 16 September 2009 (D). Images obtained from NOAA/ESRL Physical Sciences Division, Boulder Colorado at http://www.esrl.noaa.gov/psd.

of moderate to high intensity which developed moving towards the Venice Lagoon. Between 04:00 and 05:00 UTC, the convection type changed to become multi-cellular, in concomitance with the advection of very humid and unstable air from east. For many hours different cells regenerated much over the same geographical area. The main system took the form of a north-south aligned mesoscale convective system (MCS) with very low translation velocity causing large local rain accumulations. Between 05:00 and 06:00 UTC the system reached its maximum intensity, during which a number of rain gauges measured extremely high rain rates peaking at more than $90 \mathrm{~mm}$ in $30 \mathrm{~min}, 120 \mathrm{~mm}$ in one hour and $200 \mathrm{~mm}$ in three hours. From 07:00 UTC the system developed a clear V-shape and caused floods in the densely populated urban area of Venice-Mestre. During the rest of the morning the MCS propagated slowly eastwards onto the Adriatic Sea, maintaining moderate to high rainfall intensities. A second multicell system developed over the
Po river Delta again propagating eastwards onto the sea (see Figures in Rossa et al., 2010a).

Again, looking at the surface-level wind field, a distinct interaction between a south-easterly and a north-easterly flow is evident, yielding a characteristic convergence pattern just offshore of the Venice Lagoon (Fig. 9b). The synoptic flow was moderate to weak in the layer between the surface an the $700 \mathrm{hPa}$ level, where the flow did not exceed $12 \mathrm{kn}$. Equivalent potential temperature differences for this layer were 4$5 \mathrm{~K}$ and negative, indicating convective instability. As for the 17 September 2006 case, a convectively unstable flow around regime seems to apply, so that the convergence field triggered the deep convection while the synoptic setting evolved on a timescale much longer than a convective timescale, resulting in extremely high rainfall accumulations.

The precipitation map in Fig. 10b shows the observed daily rainfall accumulation, most of which was recorded in $12 \mathrm{~h}$ or less. The strong and persistent convective system 


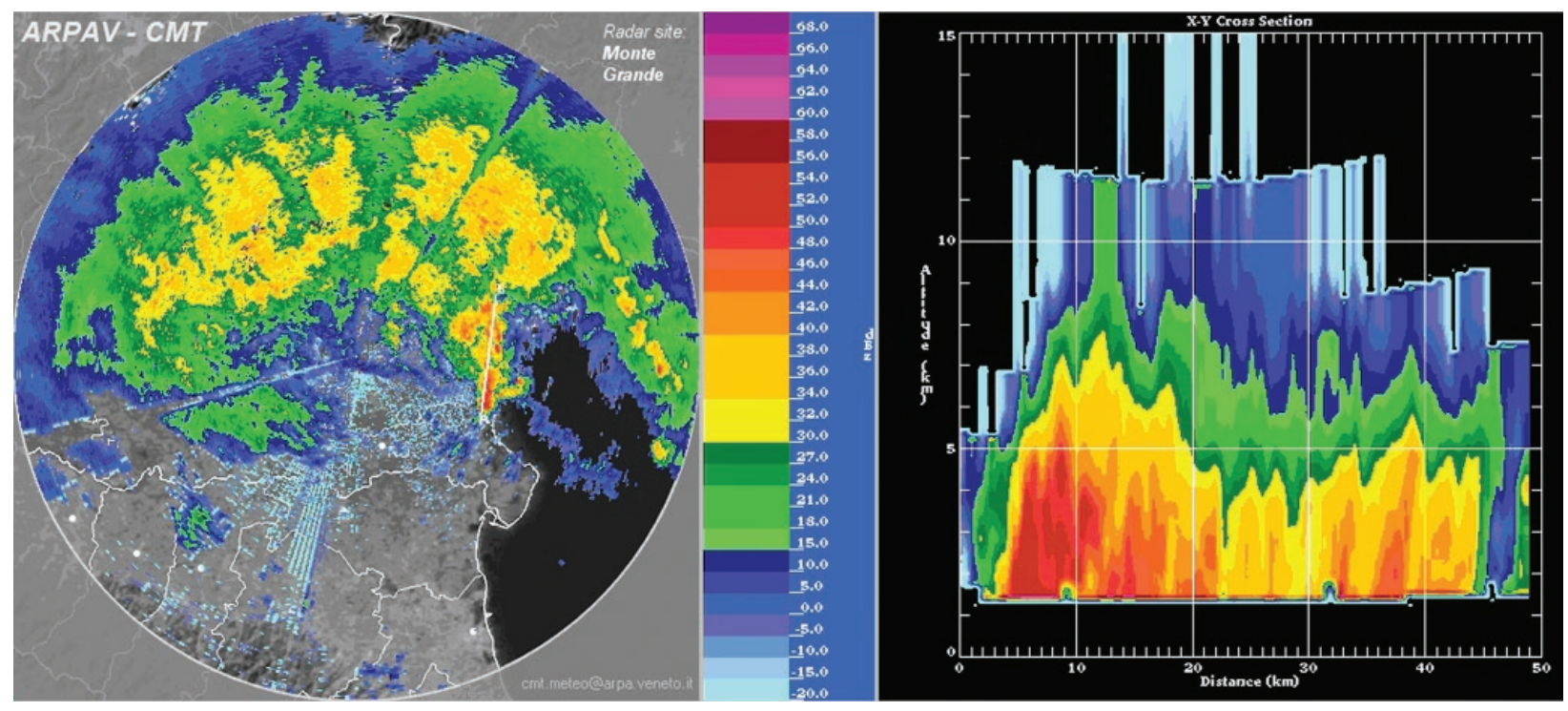

Fig. 8. Left panel shows the reflectivity from the Mt. Grande radar for the $2.4^{\circ}$ elevation PPI, on 16 September 2009 at $12: 50$ UTC. The right panel shows a vertical cross section along the line $\mathrm{AB}$ drawn in the left panel.

produced precipitation in excess of $320 \mathrm{~mm}$ in $12 \mathrm{~h}$, more than $240 \mathrm{~mm}$ fell in $3 \mathrm{~h}$ at the Valle Averto rain gauge station, with a local maximum intensity of $127 \mathrm{~mm} \mathrm{~h}^{-1}$ recorded at the Mestre rain gauge station.

\subsection{September 2008 case}

The synoptic setting for the 13 September 2008 case (Fig. 5c) again showed a broad upper-level trough on the northern Atlantic from which a secondary upper-level low cut off over France. The lower levels were influenced by a surface low on the Gulf of Genoa and on the Gulf of Taranto in southern Italy, again contributing to enhance the south-easterly moist flow along the Adriatic Sea. In the ten days prior to the event, anticyclonic conditions prevailed on the Central Mediterranean basin in form of an upper-level ridge extending from North-Africa to the Balkans (Figs. 6c and 7c).

The radar imagery (not shown) documents that convective activity started in the early hours of 13 September over the Adriatic Sea and the Apennine Mountains located south of Veneto. At about 08:00 UTC, a merging took place of the existing precipitation areas propagating northward onto the Veneto territory with a small area of organized convection which formed at 07:00 UTC over the Adriatic just offshore of the Venice Lagoon and propagated westward onto the coast. After the merging had taken place, the precipitation became widespread and covered most of the central portion of the Veneto plain with distinct lines of embedded convection. The entire precipitation system slowly propagated north-eastward. By 13:00 UTC another line of organized convection had formed over southern Veneto and the adjacent Adriatic, constantly regenerating and, by 17:00 UTC, an MCS established in the area of the city of Chioggia, located at the southern end of the Venice Lagoon. The system became quasi-stationary over the area for about three hours and propagated eastward only slowly, maintaining its northsouth orientation, onto the Adriatic continuing to keep a distinct dynamical identity throughout the night, i.e. for another ten hours of more or less constant regeneration. By midday of 14 September the convective activity was significantly reduced and limited to isolated showers. The convection throughout the event was moderate to strong with reflectivity values between 40 and $50 \mathrm{dBZ}$, with peaks exceeding $50 \mathrm{dBZ}$, especially for the evening MCS in the Chioggia area. The convective cores were of limited vertical extension, reaching only about $5-7 \mathrm{~km}$.

Inspection of the surface-level wind field shows a distinct interaction between a south-easterly and a north-easterly flow, again yielding a characteristic convergence pattern just offshore of the Venice Lagoon (Fig. 9c). The synoptic flow was weak in the layer between the surface and the $700 \mathrm{hPa}$ level, where the flow did not exceed $6 \mathrm{kn}$. Equivalent potential temperature differences for this layer is about $7 \mathrm{~K}$ and negative, indicating convective instability. This is another case for which a convectively unstable flow around regime seems to apply, so that the convergence field contributed to form and maintain the convective activity and the synoptic setting evolved on a timescale which was much longer than a convective timescale, resulting in extremely high rainfall accumulations.

Also for this case, most of the rainfall accumulations were recorded in less than $12 \mathrm{~h}$, in particular in various locations these values exceeded $100 \mathrm{~mm}$ in $24 \mathrm{~h}$ with maximum values of $177 \mathrm{~mm}$ for the Rosolina and $254 \mathrm{~mm}$ for the Chioggia rain gauge station, both located on southern Veneto coast (Fig. 10c). 

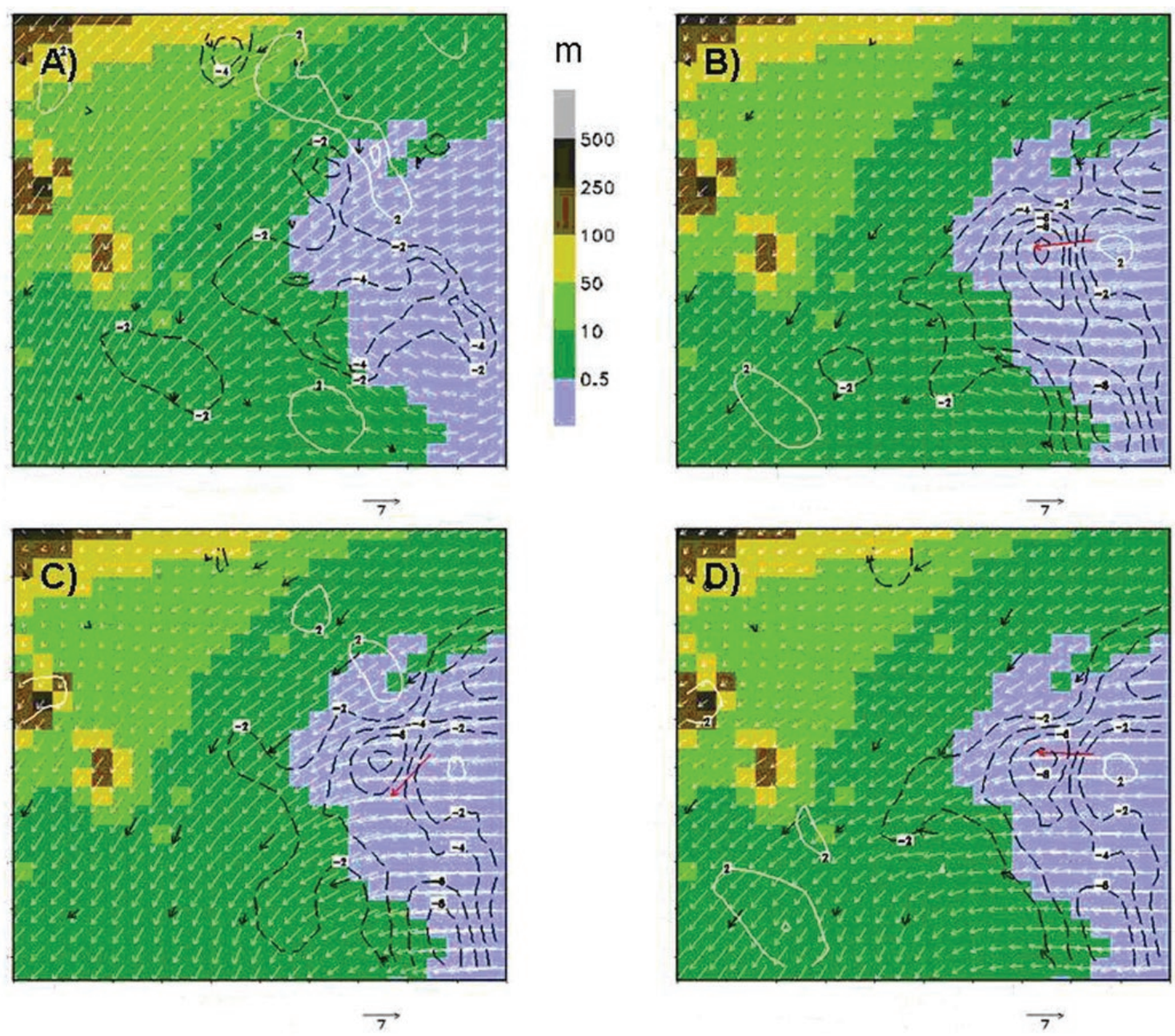

Fig. 9. Wind $\left(\mathrm{m} \mathrm{s}^{-1}\right)$ as observed by the ARPAV automatic surface station network (black arrows), from offshore buoy (red vector) and derived convergence fields (contour interval $2 \times 10^{-4} \mathrm{~s}^{-1}$, black lines negative values for convergence, white lines positive values for divergence, zero line omitted, arrow length as shown below panels denotes a wind speed of $7 \mathrm{~m} \mathrm{~s}^{-1}$ ), for 17 September 2006 03:00 UTC (panel A), 26 September 2007 01:00 UTC (panel B), 13 September 2008 08:00 UTC (panel C), and 16 September 2009 00:00 UTC (panel D). White vectors denote the gridded wind as done by the CALMET model (see Sect. 2).

Table 3. Summary of maxima of precipitation fallen in $12 \mathrm{~h}(\mathrm{~mm})$ and the ratio to total annual mean $(\%)$ recorded in some coastal stations during the events analyzed.

\begin{tabular}{llrr}
\hline Station & $\begin{array}{l}\text { Date of } \\
\text { event }\end{array}$ & $\begin{array}{r}\text { Precipitation } \\
\text { in 12h }(\mathrm{mm})\end{array}$ & $\begin{array}{r}\text { Ratio } \\
P \text { 12 } / \mathrm{P} \text { annual } \\
\text { average (\%) }\end{array}$ \\
\hline Valle Averto & 26 Sep 2007 & 322 & $41 \%$ \\
Mestre Marghera & 26 Sep 2007 & 258 & $37 \%$ \\
Chioggia (S. Anna) & 13 Sep 2008 & 254 & $32 \%$ \\
Valle Averto & 16 Sep 2009 & 163 & $20 \%$ \\
Mira & 16 Sep 2009 & 152 & $18 \%$ \\
Valle Averto & 17 Sep 2006 & 121 & $15 \%$ \\
\hline
\end{tabular}


Table 4. Summary of the four heavy precipitation events on the coastal area (2006, 2007, 2008, 2009), and on the pre-alpine chain (1999, 2010) analysed in terms of a rough airmass characterization and precipitation. Column "Raso" refers to the radio sounding of S. Pietro Capofiume (WMO code 16144), for which wind speed ("ff") and direction ("dd") are reported for the surface level and a level (reported in

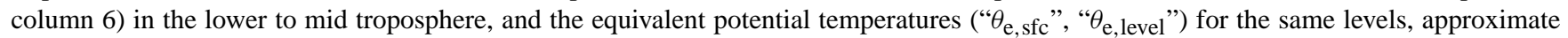
observed maximum precipitation accumulation (column 7) with the respective start and end time of the event. The final column contains a synthetic description of the airflow and precipitation characteristics.

\begin{tabular}{|c|c|c|c|c|c|c|c|}
\hline Case & Raso & $\begin{array}{r}\mathrm{ff} \\
(\mathrm{knots})\end{array}$ & dd & $\begin{array}{r}\theta_{\mathrm{e}, \mathrm{sfc}} \\
(\mathrm{K})\end{array}$ & $\begin{array}{r}\theta_{\mathrm{e}, \text { level }} \\
(\mathrm{K})\end{array}$ & $\begin{array}{r}\text { accumulation } \\
(\mathrm{mm}), \text { event start and end time }\end{array}$ & $\begin{array}{l}\text { main airflow and } \\
\text { precipitation characteristics }\end{array}$ \\
\hline 2006 & 17 Sep 00:00 UTC & $6-16$ & $\mathrm{~N} / \mathrm{NE}$ & 323.3 & $316.7(500 \mathrm{hPa})$ & 100, 00:00-23:00 UTC 17 Sep & $\begin{array}{l}\text { moderate to weak flow, unstable, wide } \\
\text { spread rain }\end{array}$ \\
\hline 2007 & 26 Sep 00:00 UTC & $4-12$ & $\mathrm{~S} / \mathrm{SO}$ & 317.9 & $313.5(700 \mathrm{hPa})$ & 250-300, 01:00-13:00 UTC 26 Sep & $\begin{array}{l}\text { moderate to weak flow, unstable, orga- } \\
\text { nized convection }\end{array}$ \\
\hline 2008 & 13 Sep 00:00 UTC & $0-6$ & $\mathrm{~N}$ & 334.3 & $327.6(700 \mathrm{hPa})$ & 200-250, 09:00-20:00 UTC 13 Sep & $\begin{array}{l}\text { weak flow, unstable, scattered } \\
\text { convective rain. }\end{array}$ \\
\hline 2009 & 16 Sep 00:00 UTC & $8-19$ & $\mathrm{~S}$ & 326.6 & $318.5(700 \mathrm{hPa})$ & 150-175, 00:00-15:00 UTC 16 Sep & $\begin{array}{l}\text { Moderate flow, unstable, wide spread } \\
\text { rain }\end{array}$ \\
\hline 1999 & 20 Sep 00:00 UTC & $9-31$ & deep SW & 330.5 & $330.8(500 \mathrm{hPa})$ & 300, 00:00-21:00 UTC 20 Sep & $\begin{array}{l}\text { strong flow, neutral, persistent rain on } \\
\text { pre-alpine chain }\end{array}$ \\
\hline 2010 & 1 Nov 00:00 UTC & $17-45$ & deep SW & 315.6 & $316.1(700 \mathrm{hPa})$ & 500, 02:00 UTC 31 Oct-15:00 UTC 02 Nov & $\begin{array}{l}\text { strong flow, weakly stable, persistent } \\
\text { rain on pre-alpine chain }\end{array}$ \\
\hline
\end{tabular}

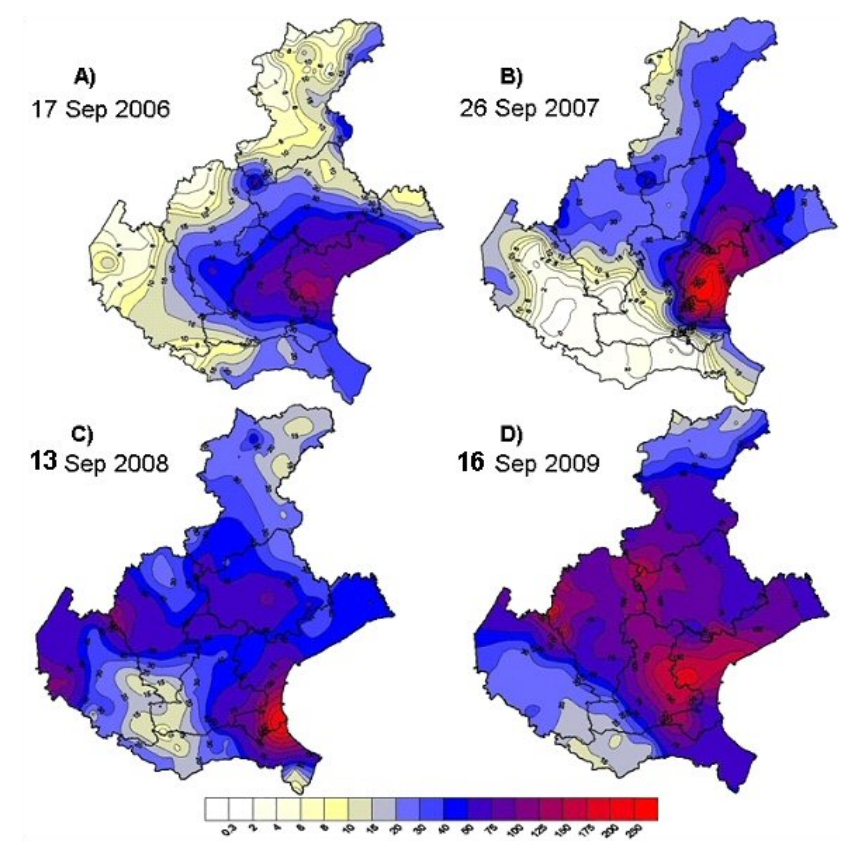

Fig. 10. Total daily precipitation accumulation $(\mathrm{mm})$ for 17 September 2006 (A), 26 September 2007 (B), 13 September 2008 (C) and 16 September 2009 (D), obtained by Kriging interpolation of 160 rain gauge stations.

\subsection{September 2009 case}

The synoptic setting for the 16 September 2009 case (Fig. 5d) was again dominated by an upper-level trough, which produced a cut-off low centred over northern Spain. At low levels, there was a south-easterly advection of warm and moist air along the Italian peninsula. In the 9-10 days prior to the event, again anticyclonic conditions prevailed over Central and Western Europe due to the presence of an upper-level ridge extending from the Azores and North Africa onto the European continent, while at the surface a large high pressure field developed over Europe from 10 until 13 September with a pressure maximum centred on the British Islands. Starting 15 September, an upper-level, cut-off low was present on the Iberian Peninsula and the Western Mediterranean, while the North African ridge shifted to the Eastern Mediterranean basin (Figs. 6d and 7d).

On 16 September 2009 there was the onset of a persistent moist south-easterly low level flow along the Adriatic onto the Veneto coast, which brought continuous rainfall throughout the 16 September. The largest accumulations were recorded just inland near the central portion of the Veneto coast, with peak values of more than $160 \mathrm{~mm}$ in $12 \mathrm{~h}$ and $70 \mathrm{~mm}$ in $1 \mathrm{~h}$.

Radar imagery shows the northward advection of convective systems onto the Veneto plain and the mountain barrier to the north (Fig. 8). The reflectivity was moderately strong with values of 45-50 dBZ, and showed limited vertical development up to only about $5-7 \mathrm{~km}$. During the early morning hours, cells started regenerating on the coastal area leading to stationary and intense rainfall. In fact, while the cells propagating with the main flow reached the pre-alpine chain (03:00 UTC), the cells on the coastal area kept merging with new cells being advected from the south (at 03:40 UTC) to form a convective line that continued until 04:30 UTC. After a two-hour break, new systems of thunderstorms formed at 06:20 UTC and slowly propagated toward the northwest, a phase that lasted until 11:00 UTC with the reflectivity peaking around $50 \mathrm{dBZ}$ but again with limited vertical development (on average less than 5-6 km). At 11:00 UTC, convective cells began to stagnate their progression in that they 
regenerated upstream and were fed from the east, developing into a stationary $\mathrm{V}$-shaped convective system which brought intense rainfall on a circumscribed area of the southern Veneto coast for two to three hours. This regeneration process continued through the entire afternoon until the evening hours, but most of the rain fell over the Adriatic.

Inspection of the surface-level wind field reveals a distinct interaction between an easterly flow on the Adriatic and a north-easterly flow on much of the Veneto plain, again yielding the characteristic convergence pattern just offshore the Veneto coast during most of the 16 September (Fig. 9d). The synoptic flow was moderate in the layer between the surface an the $700 \mathrm{hPa}$ level, where the flow intensities were between 8 and $19 \mathrm{kn}$. Equivalent potential temperature differences were high for this layer with about $8 \mathrm{~K}$ difference, indicating a strong convective instability for this layer. Again, a convectively unstable flow around the regime seems to apply, even if perhaps to a lesser extent compared with the 2007 and 2008 cases, as much of the rainfall indeed reached the pre-alpine barrier. Still, the convergence field is likely to have played a key role in maintaining the convective cells stationary by feeding warm and moist air extending their lifetime well beyond typical convective lifetimes, here in the order of $12 \mathrm{~h}$ or more. Propagation of this organized convection was not, therefore, with the mean flow but, rather, with the progression of the synoptic setting, resulting in very high rainfall accumulations.

The fourth case brought heavy and persistent rainfall on 16 September 2009 onto the central coastal and adjacent inland areas (Fig. 10d). The maximum daily rainfall accumulation was $184 \mathrm{~mm}$ for the Valle Averto rain gauge station, $169 \mathrm{~mm}$ for the Mira rain gauge station, and $158 \mathrm{~mm}$ for the Cavallino rain gauge station, with peaks of more than $160 \mathrm{~mm}$ in $12 \mathrm{~h}$.

\subsection{Discussion}

It is particularly noteworthy that the rainfall values recorded for the short accumulation periods during the analyzed events were extremely high and constitute a very significant fraction of the total mean annual amount, i.e. in the order of $15-40 \%$ (Table 3). From these values, one can appreciate how individual events of this magnitude contribute to the significantly higher concentration expressed with the concentration index (CI) found in Sect. 3 for the coastal area.

In summary, all four cases of heavy coastal precipitation are characterized by weak to moderate, statically unstable synoptic-scale flow in the lower half of the troposphere directed onto the southern side of the Alpine mountain barrier. Stable fair weather for a prolonged period of time seems to have preconditioned the air masses, along with the sea surface temperature of the Adriatic, thus providing ample moisture supply. The weak lower tropospheric flow was blocked by the Alpine barrier and deflected westward to form a characteristic, low-level convergence pattern located just offshore of the Veneto coastal area. This convergence seems to play a key role in triggering and sustaining moderate to intense organized convective precipitation patterns on the coastal area. As this flow configuration is synoptically driven, it has the potential to sustain precipitation systems with convective rainfall rates but much longer lifetimes than typical for convective systems. As a matter of fact, in the 26 September 2007 and the 16 September 2009 case the mesoscale convective systems which caused flash flooding of the coastal area continued to produce significant heavy rainfall over the Adriatic Sea for 6 to $12 \mathrm{~h}$ before dissipating. This slow eastward propagation was associated with the eastward development of the upper-level trough and the associated low-level cyclone and flow.

In Table 4, a rough air mass characterization is reported for two more cases which are more representative for the abundant autumnal rainfall which typically falls on the pre-alpine barrier. One is the MAP IOP2b case, which is well documented in the literature (e.g. Rotunno and Houze, 2007), the other a case that caused severe fluvial flooding of the Bacchiglione river in Veneto. The general synoptic setting is similar to the characteristic, upper-level trough extending into the Western Mediterranean Basin and inducing southerly flow onto the Alpine mountain range. Inspection of the flow intensity and static stability of the flow reveals that the flows are less convectively unstable and much more intense, so that the coastal convergence pattern does not develop and most of the humidity is released as orographic rain on the pre-alpine mountain range.

\section{Conclusions}

In this paper, four cases of heavy precipitation on the flat, coastal area of the north-eastern Italian region of Veneto were examined to illustrate and substantiate the peculiar feature of the Veneto coastal area precipitation climatology, which is characterized by a lower mean annual accumulation but a significantly higher occurrence of stronger rainfall, especially when compared with the rainiest areas found on the pre-alpine barrier. This was done by means of observational analysis with the aim to quantify this behaviour and to illustrate the mechanisms that lead to the specific localization of the heavy precipitation patterns on the coastal area distinctly away from the Alpine mountain barrier, which is located some $100 \mathrm{~km}$ north of the coast. The following findings appear to be key ingredients for all the events:

- All cases took place in September in association with the eastward passage of an upper-level Atlantic trough into the Mediterranean area with low-level advection of warm and moist air from the Adriatic Sea, which still featured sea surface temperatures well exceeding $20^{\circ} \mathrm{C}$, values above normal for the period. 
- The cases occurred after a prolonged anticylonic period with temperatures higher than normal and humid air.

- Flow intensities were moderate to weak, especially at lower levels compared to typical autumnal situations. Flow direction was predominantly from southerly sectors, but one case featured a significant easterly component.

- The flows tended to be statically unstable and favour deep convection.

- The low-level convergence pattern in the coastal area, common to all four cases, is suggested to be the product of flow convergence of the southerly large-scale winds with the blocked, barrier-type winds which are from easterly sectors in the eastern Po Valley and, as such, are characteristic for the geometrical setting of the area.

- In contrast, two more typical autumnal cases differed from the analyzed ones in that one, the MAP IOP2b case, which featured a stronger, vertically more coherent south-westerly flow with weak static stability, while the other autumnal case was characterized by a much stronger and persistent flow.

- The characteristic, orographically induced low-level convergence pattern in a convectively unstable atmosphere gave rise to organized precipitation systems exhibiting convective precipitation rates but durations which exceeded typical convective timescales, thus resulting in significant rainfall accumulations (15-40\% of mean annual rainfall).

Heavy rainfall events as presented in this paper are suggested to modulate the precipitation climatology of the Veneto coastal area, which seems to share characteristics common to other Mediterranean coastal areas, in that the:

- mean total annual rainfall is relatively low if compared with neighbouring areas;

- maximum daily rainfall accumulations can be very significant compared with the mean annual amount;

- the level of concentration in the distribution of daily precipitation is significantly larger than for areas located away from the coast, reaching $80 \%$ or more of the annual rainfall in $25 \%$ of the rainiest days.

In summary, one might conceptually describe the cases of heavy coastal rainfall as predominantly convective in nature but dynamically driven and sustained by an orographically modified synoptic flow configuration, giving rise to high and persisting rainfall rates with consequently very significant rainfall accumulations. The flow geometry was found to be such that the characteristic convergence line resulting from the low-level flow from southerly directions and the barriertype flow is located close to the densely populated and touristic area of the Venetian Adriatic coast, making it especially relevant. This effect is sufficiently recurrent that a clear signature is present in the precipitation climatology of the Veneto coastal area.

Acknowledgements. The authors thankfully acknowledge ARPA Friuli Venezia Giulia for providing the data buoys Trieste and Lignano, as well as the Centro Previsioni e Segnalazioni Maree Venezia for the data of the Istituto di Scienze Marine platform located just offshore of the Venice Lagoon. Also, thanks are due to our colleagues, M. Ferrario for preparing the convergence fields, and G. Cenzon for preparing and discussing the radar imagery of the precipitation events.

Edited by: K. Lagouvardos

Reviewed by: two anonymous referees

\section{References}

Barbi, A., Millini, R., Monai, M., and Sofia, S.: Meteo-climatic features of the Venice Lagoon, in: Flooding and Environmental Challenges for Venice and its Lagoon: State of Knowledge, edited by: Fletcher, C. A. and Spencer, T., Cambridge University Press, Cambridge, UK, 79-84, 2005.

Barbi, A., Formentini, G., and Monai, M.: The 26TH September 2007 Venice extreme convective rainfall event. Extended abstract, Poster session in 15th International Conference on Clouds and Precipitation, Cancun-Mexico, 7-11 Luglio 2008, available at: http://cabernet.atmosfcu.unam.mx/ICCP-2008/, 2008.

Bougeault, P., Binder, P., Buzzi, A., Dirks, R., Houze, R., Kuettner, J., Smith, R. B., Steinacker, R., and Volkert, H.: The MAP Special Observing Period, B. Am. Meteorol. Soc., 82, 433-462, 2001.

Camuffo, D., Tampieri, F., and Zambon, G.: Local mesoscale circulation over Venice as a result of the mountain-sea interaction, Bound.-Lay. Meteorol., 16, 83-92, 1979.

Davolio, S., Mastrangelo, D., Miglietta, M. M., Drofa, O., Buzzi, A., and Malguzzi, P.: High resolution simulations of a flash flood near Venice, Nat. Hazards Earth Syst. Sci., 9, 1671-1678, doi:10.5194/nhess-9-1671-2009, 2009.

De Luis, M., Gonzalez-Hidalgo, J. C., Ravent'os, J., Sanchez, J. R., and Cortina, J.: Distribucion espacial de la concentracion y agresividad dela lluvia en el territorio de la Comunidad Valenciana, Cuaternario y Geomorfologia, 11, 33-44, 1997.

Homar, V., Romero, R., Ramis, C., and Alonso, S.: Numerical study of the October 2000 torrential precipitation event over eastern Spain: analysis of the synoptic-scale stationarity, Ann. Geophys., 20, 2047-2066, doi:10.5194/angeo-20-2047-2002, 2002.

Kalnay, E., Kanamitsu, M., Kistler, R., Collins, W., Deaven, D., Gandin, L., Iredell, M., Saha, S., White, G., Woollen, J., Zhu, Y., Chelliah, M., Ebisuzaki, W., Higgins, W., Janowiak, J., Mo, K.C., Ropelewski, C., Wang, J., Jenne, R., and Joseph, D.: The NCEP/NCAR Reanalysis 40-year Project, B. Am. Meteorol. Soc., 77, 437-471, 1996.

Lebeaupin, C., Ducrocq, V. and Giordani, H.: Sensitivity of torrential rain events to the sea surface temperature based on high- 
resolution numerical forecasts, J. Geophys. Res., 111, D12110, doi:10.1029/2005JD006541, 2006.

Lionello, P., Bhend, J., Buzzi, A., Della-Marta, P. M., Krichak, S., Jans'a, A., Maheras, P., Sanna, A., Trigo, I. F., and Trigo, R.: Cyclones in the Mediterranean region: climatology and effects on the environment, in Mediterranean Climate Variability, edited by: Lionello, P., Malanotte-Rizzoli, P., and Boscolo, R., Elsevier, Amsterdam, The Netherlands, 324-372, 2006.

Martin-Vide J.: Spatial distribution of a daily precipitation concentration index in peninsular Spain, Int. J. Climatol., 24, 959-971, 2004.

Miglietta, M. M. and Regano, A.: An observational and numerical study of a flash-flood event over south-eastern Italy, Nat. Hazards Earth Syst. Sci., 8, 1417-1430, doi:10.5194/nhess-8-1417-2008, 2008.

Monai, M., Rossa, A., Formentini, G., and Veronese, S.: Multisensor analysis of extreme events in North-Eastern Italy, Adv. Geosci., 2, 167-171, doi:10.5194/adgeo-2-167-2005, 2005.

Monai, M., Rossa, A. M., and Bonan, A. C.: Partitioning of snowy and rainy precipitation in a case of a north Adriatic frontal passage, Adv. Geosci., 7, 279-284, doi:10.5194/adgeo-7-279-2006, 2006.
Romero, R., Ramis, C., and Guijarro, J.A.: Daily rainfall patterns in the Spanish Mediterranean area: an objective classification, Int. J. Climatol., 19, 95-112, 1999.

Rossa, A. M., Cenzon, G., and Monai, M.: Quantitative comparison of radar QPE to rain gauges for the 26 September 2007 Venice Mestre flood, Nat. Hazards Earth Syst. Sci., 10, 371-377, doi:10.5194/nhess-10-371-2010, 2010a.

Rossa, A., Laudanna Del Guerra, F., Borga, M., Zanon, F., Settin, T., and Leuenberger, D.: Radar-driven High-resolution Hydrometeorological Forecasts of the 26 September 2007 Venice Flash Flood, J. Hydrol., 394, 230-244, 2010 b.

Rotunno, R. and Houze, R.: Lessons on orographic precipitation from the Mesoscale Alpine Programme, Q. J. Roy. Meteo. Soc., Wiley Online Library, 133, 811-830, 2007.

Scire, J., Robe, F., Fernau, M., and Yamartino, R.: A user's guide for the CALMET meteorological model, Earth Tech, USA, 2000.

Smith, R.: The influence of mountains on the atmosphere, Adv. Geophys., Elsevier, 21, 87-230, 1979. 